\title{
PENGARUH PENDIDIKAN KEWIRAUSAHAAN DAN KETERAMPILAN BERWIRAUSAHA TERHADAP MOTIVASI BERWIRAUSAHA MAHASISWA PENDIDIKAN EKONOMI UNIVERSITAS NEGERI MEDAN
}

\author{
Putri Kemala Dewi Lubis ${ }^{1)^{*}}$ \\ ${ }^{1)}$ Fakultas Ekonomi, Universitas Negeri Medan \\ Email: putrikemaladewilubis.unimed@gmail.com
}

\begin{abstract}
Abstrak
Penelitian ini bertujuan untuk menganalisis (1) besarnya pengaruh pendidikan kewirausahaan terhadap motivasi berwirausaha mahasiswa pendidikan ekonomi (2) besarnya pengaruh keterampilan berwirausaha terhadap motivasi berwirausaha mahasiswa pendidikan ekonomi (3) besarnya pengaruh pendidikan kewirausahaan dan keterampilan berwirausaha terhadap motivasi berwirausaha mahasiswa pendidikan ekonomi Universitas Negeri Medan. Penelitian ini merupakan penelitian asosiatif kausal dengan pendekatan kuantitatif. Variabel penelitian ini adalah pendidikan kewirausahaan dan keterampilan berwirausaha sebagai variabel bebas, motivas berwirausaha sebagai variabel terikat. Penelitian ini merupakan penelitian populasi dengan responden mahasiswa pendidikan ekonomi angkatan 2015 yang berjumlah 60 mahasiswa. Teknik pengambilan data menggunakan kuesioner dan dokumentasi. Metode analisis data yang digunakan adalah regresi linier berganda. Hasil penelitian ini menunjukkan bahwa (1) Pendidikan kewirausahaan berpengaruh positif dan signifikan terhadap motivasi berwirausaha ditunjukkan oleh nilai F hitung 17,163 dengan nilai signifikansi 0,000 dan R2 0,228. (2) Pendidikan kewirausahaan berpengaruh positif dan signifikan keterampilan berwirausaha dengan ditunjukkan oleh nilai F Hitung 61,093 dengan nilai signifikansi 0,000 dan R2 0,513..
\end{abstract}

Keywords: Pendidikan Kewirausahaan, Motivasi Berwirausaha, Keterampilan berwirausaha 
Pengangguran menjadi masalah serius dipemerintah, dunia pendidikan, dunia industri, Indonesia yang masih sulit diatasi. Programmaupun masyarakat. Fenomena ini semakin pemerintah untuk mengurangi pengangguranmenambah beban pemerintah dalam mengurangi belum mampu mengurangi pengangguran secarapengangguran.

signifikan. Penyebabnya karena jumlah penduduk Salah satu solusi yang ditempuh untuk yang besar dan pertumbuhan penduduk yangmengatasi pengangguran di Indonesia adalah semakin meningkat, tidak disertai bertambahnyadengan menciptakan wirausaha. Dengan lapangan kerja. Pengangguran terbuka menurutberwirausaha, akan membantu pemerintah dalam pendidikan tertinggi yang ditamatkan jugamenciptakan lapangan pekerjaan baru. Dengan terhitung masih tinggi. Hal ini dapat dikatakanberwirausaha selain berpeluang menghasilkan pengangguran banyak terjadi pada penduduk yangpendapatan yang besar bagi wirausaha, juga berpendidikan. mampu mengurangi jumlah pengangguran. Para

Pengangguran bukanlah hasil sebuahwirausaha juga berkontribusi kepada pilihan untuk tidak bekerja, tetapi akibat dariperekonomian negara melalui pajak yang semakin sulitnya mendapatkan pekerjaan.dihasilkan.

Terutama di kota-kota besar, dimana jumlah angka Dalam menciptakan seorang wirausaha lulusan perguruan tinggi yang setiap tahundapat dimulai melalui pendidikan kewirausahaan bertambah, namun lapangan pekerjaan yangyang diajarkan di perguruan tinggi, tetapi akan tersedia semakin sempit. Hal inilah yang menjadilebih cepat apabila pendidikan kewirausahaan juga salah satu penyebab meningkatnya jumlahmulai diterapkan dari keluarga, masyarakat dan pengangguran karena adanya tingkat persainganlembaga pendidikan. Pada dasarnya pendidikan dalam melamar pekerjaan semakin tinggi.dapat dijadikan sebagai jembatan penghubung bagi Lapangan kerja yang terbatas membuat orangmanusia menuju kehidupan yang lebih baik. mencari jalan untuk bertahan hidup agar dapatPendidikan kewirausahaan diharapkan mampu hidup dengan layak. membangkitkan semangat berwirausaha, berdikari,

Jumlah lulusan dari tahun ke tahun terusberkarya dan mengembangkan perekonomian meningkat, namun peningkatan tersebut tidaknasional (Jamal Ma'mur Asmani: 2011)

diimbangi oleh pertambahan jumlah lapangan Pendidikan kewirausahaan tidak hanya pekerjaan. Sehubungan dengan hal tersebut makamemberikan landasan teoritis mengenai konsep sangatlah penting pembangunan kewirausahaankewirausahaan tetapi membentuk sikap, perilaku, bagi remaja dikalangan mahasiswa khususnya didan pola pikir (mindset) seorang wirausaha. Hal Universitas Negeri Medan jurusan Pendidikanini merupakan investasi modal untuk Ekonomi. Pendorong munculnya kebutuhan akanmempersiapkan para mahasiswa dalam memulai berwirausaha adalah munculnya beraneka ragambisnis baru melalui integrasi pengalaman, kesempatan berusaha dalam era perkembanganketerampilan, dan pengetahuan penting untuk teknologi tinggi. Melihat perkembanganmengembangkan dan memperluas sebuah bisnis. kehidupan manusia yang sangat cepat dan tanpa Jurusan Pendidikan Ekonomi Fakultas batas, tantangan masa depan denganEkonomi Universitas Negeri Medan, sudah perkembangan dan persaingan yang sangat ketat,menerapkan pendidikan kewirausahaan. maka harus dipersiapkan pembangunan sumberPendidikan kewirausahaan sudah masuk dalam daya manusia diberbagai bidang kehidupan. kurikulum yang mewajibkan mahasiswa

Tingkat pengangguran terdidik yangpendidikan ekonomi menempuh pendidikan berstatus sarjana juga dikhawatirkan akan teruskewirausahaan. Pendidikan Kewirausahaan ini meningkat jika perguruan tinggi sebagai lembagadibagi menjadi menjadi dua mata kuliah, yaitu pencetak sarjana tidak memiliki kemampuanmata kuliah kewirausahaan yang ditempuh pada mengarahkan peserta didik dan alumninyasemester lima dan praktikum kewirausahaan yang menciptakan lapangan kerja setelah lulus nanti.ditempuh pada semester enam. Mata kuliah Ditambah dengan rendahnya motivasi generasitersebut diterapkan berupa teori dan praktik muda Indonesia dalam berwirausaha saat iniberwirausaha. Pendidikan kewirausahaan yang 
berupa teori diberikan didalam kelas untukatau keorganisasian hendaknya juga diarahkan pembekalan sebelum mahasiswa terjun menjadiuntuk memberikan keterampilan berwirausaha.

wirausaha, sedangkan yang berupa praktek kerja Motivasi Berwirausaha

melalui kegiatan melakukan survey yang Motivasi berwirausaha adalah dorongan dilakukan mahasiswa ke tempat usaha dankuat dari dalam diri seseorang untuk memulai perusahaan-perusahaan kecil.

Fenomena rendahnya motivasidan inovatif untuk menciptakan produk baru dan berwirausaha dewasa ini menjadi pemikiran seriusbernilai tambah guna kepentingan bersama. berbagai pihak, baik pemerintah, duniaWirausaha akan muncul ketika seseorang berani pendidikan, dunia industri, maupun masyarakat.mengembangkan usaha-usaha dan ide-ide barunya. Berbagai upaya dilakukan untuk menumbuhkanMembuat seseorang menjadi berani jiwa entrepreneurship terutama merubah mindsetmengembangkan usaha dan idenya melalui para pemuda yang selama ini hanya berminatmotivasi berwirausaha yang kuat. Dua hal tersebut sebagai pencari kerja (job seeker) apabila kelakharus saling berhubungan agar tercipta wirausaha menyelesaikan kuliah mereka. Hal ini merupakanyang kuat dan tangguh serta berkualitas.

tantangan bagi perguruan tinggi sebagai lembagaMenurut Basrowi (2011: 67-68), motivasi penghasil lulusan..

seseorang menjadi wirausaha, yaitu:

\section{TINJAUAN PUSTAKA}

\section{Pendidikan Kewirausahaan}

Pendidikan kewirausahaan mengajarkan penanaman nilai-nilai kewirausahaan yang akan membentuk karakter dan perilaku untukb) berwirausaha agar peserta didik dapat mandiri. Pendidikan kewirausahaan juga mampu membekali peserta didik dengan berbagaic) Impian personal. Bebas mencapai standar kompetensi kewirausahaan yang nantinya akan membawa manfaat besar bagi kehidupannya.

$$
\text { Menurut Agus Wibowo (2011:76), }
$$

a) Laba. Seorang wirausaha dapat menetukan berapa laba yang dkehendaki dan keuntungan yang akan diperoleh serta berapa yang akan dibayarkan kepada pihak lain dan karyawannya.

Kebebasan. Bebas mengatur waktu, bebas dari aturan yang menekan dan bebas dari aturan budaya organisasi.

hidup yang diinginkan, bebas dari rutinitas kerja yang membosankan. Imbalan untuk menentukan misi, visi dan impian sendiri.

terdapat dua cara untuk menanamkan mentald) Kemandirian. Memiliki rasa bangga, karena kewirausahaan kepada para mahasiswa di kampus. Pertama, mengintegrasikan pendidikan sendiri.

kurikulum, karakter keilmuan kewirausahaan Selain bekal kemampuan, wirausaha juga sebaiknya didesain untuk mengetahui (to know),perlu memiliki pengetahuam dan keterampilan. melakukan (to do), dan menjadi (to be)Bekal pengetahuan yang harus dimiliki wirausaha entrepreneur. Tujuan pendidikan to know dan tomeliputi: 1) bekal pengetahuan mengenai usaha do terintegrasi di dalam kurikulum program studi,yang akan dirintis dan lingkungan usaha yang ada terdistribusi di dalam berbagai mata kuliah2) bekal pengetahuan tentang peran dan tanggung keilmuan. Perguruan Tinggi menyediakan matajawab 3) bekal pengetahuan tentang manajemen kuliah kewirausahaan yang ditujukan untuk bekaldan organisasi bisnis. Bekal keterampilan yang motivasi dan pembentukan sikap mentalharus dimiliki wirausaha meliputi: 1) bekal wirausaha. Untuk tujuan to be entrepreneur,keterampilan konseptual dalam mengatur strategi diberikan dalam pelatihan keterampilan bisnisdan memperhitungkan risiko, 2) bekal praktis. Kedua, aktivitas ekstrakurikulerketerampilan kreatif dalam menciptakan nilai mahasiswa perlu dikemas sistemik dan diarahkantambah, 3) bekal keterampilan dalam memimpin untuk membangun motivasi dan sikap mentaldan mengelola, 4) bekal keterampilan wirausaha. Pembinaan mahasiswa dalam berbagaiberkomunikasi dan berinteraksi, 5) bekal kegiatan minat dan bakat, keilmuan, kesejahteraanketerampilan teknik usaha yang akan dilakukannya

(Rusdiana, 2014: 50).. 
NIAGAWAN Vol 7 No 2 Juli 2018

\section{METODE PENELITIAN}

Penelitian ini menggunakan pendekatanrumus korelasi product moment dari Pearson.

kuantitatif, karena data diwujudkan dalam bentuk angka dan dianalisis berdasarkan analisis statistik guna menunjukkan pengaruh pendidikan

2. Uji Reliabilitas Instrumen

Reliabilitas menunjukan bahwa sesuatu kewirausahaan terhadap motivasi berwirausahainstrumen cukup dipercaya untuk digunakan dan keterampilan berwirausaha mahasiswasebagai alat pengumpul data karena instrumen Pendidikan Ekonomi Universitas Negeri Medan.tersebut sudah baik. Reliabilitas menunjuk pada Penelitian ini juga merupakan jenis penelitiantingkat keterandalan sesuatu. Reliabel artinya asosiatif kausal, karena menganalisis hubungandapat dipercaya, jadi dapat diandalkan (Suharsimi sebab akibat antara variabel $\mathrm{Y}$ dan variabel XArikunto, 2010). Dalam penelitian ini uji secara kausal. reliabilitas dicari menggunakan rumus Alpha. Variabel Penelitian Rumus Alpha digunakan untuk mencari reliabilitas Variabel penelitian adalah suatu atribut atau nilaiinstrumen yang skornya bukan 1 dan 0 . Instrumen atau sifat dari objek atau kegiatan yangdapat dikatakan reliabel jika nilai koefisien alpha mempunyai variasi tertentu yang ditetapkan olehtersebut melebihi 0,6 (Ali Muhson: 2009)

peneliti untuk dipelajari dan kemudian ditarik

kesimpulannya (Sugiyono, 2012: 38). Adapun variabel dalam penelitian ini adalah:

\section{Uji Hipotesis}

Pengujian hipotesis adalah suatu prosedur

1. Variabel bebas (Independen) adalah variabelyang akan menghasilkan suatu keputusan, yaitu yang mempengaruhi atau yang menjadi sebabkeputusan menerima atau menolak hipotesis perubahan atau timbulnya variabel terikattersebut. Hipotesis diartikan sebagai jawaban (dependen). Dalam penelitian ini yang menjadisementara terhadap rumusan masalah penelitian. variabel bebas adalah PendidikanKebenaran dari hipotesis itu harus dibuktikan Kewirausahaan dan Keterampilanmelalui data yang terkumpul (Sugiyono, 2012: Berwirausaha (X). 159 ).

2. Variabel terikat (Dependen) adalah variabela. Regresi Linear Sederhana yang dipengaruhi atau yang menjadi akibatRegresi linear sederhana didasarkan pada karena adanya variabel bebas. Dalamhubungan kausal antara satu variabel independen penelitian ini yang menjadi variabel terikatdengan satu variabel dependen. Persamaan regresi adalah motivasi berwirausaha (Y).

linear berganda:

$\mathrm{Y}=\mathrm{a}+\mathrm{bX} 1+\mathrm{bX} 2$

\section{Populasi dan Sampel Penelitian Keterangan:}

Penelitian ini termasuk penelitian populasi $\mathrm{Y}=$ variabel terikat

karena jumlah responden kurang dari 100 yaitu 60X1, X2 = variabel bebas

mahasiswa. Adapun populasi sekaligus menjadia $=$ nilai intercept (konstan)

sampel dalam penelitian ini adalah seluruhb $=$ angka arah atau koefisien regresi

mahasiswa Pendidikan Ekonomi Universitas

Negeri Medan angkatan 2015 yang sudahb. Koefisien Determinan (R2)

mengikuti mata kuliah kewirausahaan danKoefisien determinan merupakan suatu nilai yang praktikum kewirausahaan. menjelaskan variabel bebas dalam mempengaruhi variabel terikatnya dalam suatu persamaan regresi.

\section{Teknik Analisa Data}

1. Uji Validitas Instrumen

Menurut Suharsimi adalah suatu ukuran yang menunjukan tingkat-(Sugiyono, 2011: 185).

tingkat kevalidan atau kesahihan sesuatu instrumen. Suatu instrumen yang valid atau sahih mempunyai validitas tinggi, sebaliknya instrumen 
4. Uji Asumsi Kelasik

Uji asumsi kelasik yang dilakukan berupa ujiapakah variabel dependent, independent atau multikolinieritas dan uji heteroskedastisitas..

\section{HASIL DAN PEMBAHASAN}

\section{Uji Normalitas}

Hasil uji normalitas sebagai berikut :
Uji normalitas digunakan untuk mengetahui keduanya berdistribusi normal, mendekati normal atau tidak. Untuk mengetahui apakah data itu normal atau tidak dapat dilihat dengan uji Kolmogorov-Smirnov .

Tabel 1 Hasil Uji Normalitas

\begin{tabular}{|c|c|c|c|c|c|c|}
\hline & \multicolumn{3}{|c|}{ Kolmogorov-Smirnov $^{\mathrm{a}}$} & \multicolumn{3}{|c|}{ Shapiro-Wilk } \\
\hline & Statistic & $\mathrm{df}$ & Sig. & Statistic & $\mathrm{df}$ & Sig. \\
\hline Motivasi Berwirausaha & ,103 & $\overline{60}$ & , 179 & ,979 & 60 & 4,402 \\
\hline $\begin{array}{l}\text { Pendidikan } \\
\text { Kewirausahaan }\end{array}$ &, 100 & 60 & ,200* & ,976 & 60 & ,281 \\
\hline $\begin{array}{l}\text { Keterampilan } \\
\text { Berwirausaha }\end{array}$ & ,193 & 60 & , 130 & 897 & 60 & 000 \\
\hline
\end{tabular}

Sumber: data primer yang diolah

Berdasarkan tabel di atas, dapat diketahui

bahwa ketiga variabel dalam penelitian ini berdistribusi normal. Variabel X1 (pendidikan kewirausahaan) memiliki signifikansi lebih dari 0,05 yaitu 0,200 . Variabel X2 (keterampilan berwirausaha) memiliki signifikansi lebih dari 0,05 yaitu 0,130. Variabel Y (motivasi berwirausaha) memiliki signifikansi lebih dari 0,05 yaitu 0,179 . Kesimpulan yang dapat diambil adalah ketiga variabel dalam penelitian ini berdistribusi normal.

Tabel 2. Hasil Uji Linearitas

\section{Uji Linearitas}

Uji linearitas digunakan untuk memastikan apakah hubungan antara variabel bebas dengan variabel terikat linear. Kriteria yang digunakan adalah dengan mempertimbangkan nilai signifikansi $F$. Apabila nilai sig F kurang dari 0,05 maka hubungan tidak linear, sedangkan jika nilai sig F lebih dari atau sama dengan 0,05 maka hubungannya linear. Hasil uji linearitas dapat dilihat dalam tabel di bawah ini :

\begin{tabular}{|lll|r|r|r|r|}
\hline & & & df & F & Sig. \\
\hline & & (Combined) & 28 & 4,053 &, 000 \\
& Between Groups & Linearity & Deviation & & 74,877 &, 000 \\
Motivasi Berwirausaha * & & & & \\
Keterampilan Berwirausaha & & from & 1,430 &, 168 \\
& Linearity & & & \\
& Within Groups & & 31 & & \\
& Total & & & \\
& & & & \\
\end{tabular}

Sumber: data primer yang diolah

Berdasarkan tabel di atas, dapat diketahui bahwa hubungan antara pendidikan kewirausahaan (X1) dan keterampilan berwirausaha (X2) dengan motivasi berwirausaha $(\mathrm{Y})$ bersifat linier, dengan nilai signifikansi F 74,877 (lebih besar dari 0,05) dan nilai signifikansi 0,000 kurang dari 0,05 Sehingga dapat disimpulkan data bersifat linear.
3. Uji Hipotesis secara parsial (Uji t), uji simultan (Uji F) dan Analisis linier berganda

Pengujian hipotesis dalam penelitian ini bertujuan untuk membuktikan pengaruh pendidikan kewirausahaan dan keterampilan berwirausaha terhadap motivasi berwirausaha mahasiswa Prodi Pendidikan Ekonomi Universitas Negeri Medan. 


\section{Pengujian Hipotesis dan Analisis Regresi Linier bergand}

Hasil yang diperoleh dalam penelitian ini hitungnya kurang dari 0,05 . Hasil yang diperoleh dari analisis regresi $\mathrm{X}$ terhadap $\mathrm{Y}$ dapat dilihat pada tabel berikut: dikatakan signifikan bila nilai signifikansi

Tabel 3. Hasil Uji Hipotesis (uji t) dan analisis linier berganda

\begin{tabular}{|c|c|c|c|c|c|c|}
\hline \multirow{2}{*}{\multicolumn{2}{|c|}{ Model }} & \multicolumn{2}{|c|}{$\begin{array}{l}\text { Unstandardized } \\
\text { Coefficients }\end{array}$} & \begin{tabular}{|l} 
Standardized \\
Coefficients
\end{tabular} & \multirow[t]{2}{*}{$\mathrm{t}$} & \multirow[t]{2}{*}{ Sig. } \\
\hline & & B & Std. Error & Beta & & \\
\hline \multirow{3}{*}{1} & (Constant) & 24,876 & 3,465 & & 7,178 & ,000 \\
\hline & $\begin{array}{l}\text { Pendidikan } \\
\text { Kewirausahaan }\end{array}$ &,- 063 & ,107 &,- 078 &,- 590 & ,557 \\
\hline & $\begin{array}{l}\text { Keterampilan } \\
\text { Berwirausaha }\end{array}$ & ,348 & ,059 & ,775 & 5,904 & ,000 \\
\hline
\end{tabular}

a. Dependent Variable: Motivasi Berwirausaha

Tabel di atas dapat diketahui bahwa Persamaan regresi linier berganda sebagai berikut :

Persamaan tersebut menunjukan bahwa nilai konstanta sebesar 24,876 artinya jika pendidikan kewirausahaan $\left(\mathrm{X}_{1}\right)$ dan keterampilan berwirausaha $\left(\mathrm{X}_{2}\right)$ nilainya adalah 0 maka motivasi berwirausaha nilainya adalah 24,876. Nilai koefisien regresi variabel pendidikan kewirausahaan $\left(\mathrm{X}_{1}\right)$ sebesar $-0,063$ yang berarti apabila pendidikan kewirausahaan $\left(\mathrm{X}_{1}\right)$ mengalami peningkatan sebesar satu satuan, maka motivasi berwirausaha (Y) akan mengalami penurunan 0,063 satuan. Nilai koefisien regresi variabel keterampilan berwirausaha $\left(\mathrm{X}_{2}\right)$ sebesar 0,348 yang berarti apabila keterampilan berwirausaha mengalami peningkatan sebesar satu satuan, maka motivasi berwirausaha (Y) akan mengalami peningkatan sebesar 0,348 satuan.

Hasil uji hipotesis (uji t) berdasarkan tabel diatas nilai t-hitung sebesar $-0,590$ dengan signifikasi sebesar 0,05 sedangkan nilai t-tabel sebesar 1,672. Dapat disimpulkan bahwa nilai thitung < t-tabel $(-0,590<1,672)$ artinya $\mathrm{H}_{0}$ diterima ada pengaruh positif pendidikan kewirausahaan terhadap motivasi berwirausaha mahasiswa pendidikan ekonomi Universitas Negeri Medan. Variabel keterampilan berwirausaha $\left(\mathrm{X}_{2}\right)$ nilai t-hitung sebesar 5,904 sedangkan nilai t-tabel sebesar 1,672. Dapat disimpulan bahwa nilai t-hitung $>\mathrm{t}$-tabel $(5,904$ $>1,672)$ artinya $\mathrm{H}_{0}$ ditolak tida ada pengaruh positif keterampilan berwirausaha terhadap motivasi berwirausaha mahasiswa pendidikan ekonomi Universitas Negeri Medan.

$$
\begin{aligned}
\mathrm{Y} & =\mathrm{a}+\mathrm{b} \mathrm{X}_{1}+\mathrm{b} X_{2} \\
& =\mathbf{2 4 , 8 7 6}-\mathbf{0 , 0 6 3} \mathrm{X}_{\mathbf{1}}+\mathbf{0 , 3 4 8} \mathrm{X}_{\mathbf{2}}
\end{aligned}
$$

\section{Uji Simultan ( uji F)}

Hasil uji simultan variabel dependen dan variabel independen dapat dilihat pada tabel berikut:

Hasil uji hipotesis secara simultan (Uji F) berdasarkan tabel diatas nilai F-hitung sebesar 31,020 dengan signifikasi sebesar 0,05 sedangkan nilai F-tabel sebesar 3,159. Dapat disimpulkan bahwa nilai F-hitung > F-tabel ( $31,020>3,159)$ artinya H0 ditolak tidak ada pengaruh positif pendidikan kewirausahaan dan keterampilan berwirausaha terhadap notivasi berwirausaha mahasiswa pendidikan ekonomi Universitas Negeri Medan.

Tabel 4. Hasil Uji simultan (uji F)

\begin{tabular}{|ll|l|l|}
\hline \multicolumn{2}{|l|}{ Model } & F & Sig. \\
\hline 1 & $\begin{array}{l}\text { Regression } \\
\text { Residual } \\
\text { Total }\end{array}$ & 31,020 &, $000^{\mathrm{b}}$ \\
\hline
\end{tabular}

a. Dependent Variable: Motivasi

Berwirausaha

b. Predictors: (Constant), Keterampilan

Berwirausaha, Pendidikan Kewirausahaan

\section{Koefisien determinasi (R2)}

Berdasarkan hasil analisis data, menunjukan R2 sebesar 0,521. Nilai tersebut berarti $52,1 \%$ perubahan pada variabel motivasi berwirausaha (Y) dipengaruhi oleh variabel pendidikan kewirausahaan (X1) dan keterampilan berwirausaha (X2), sedangkan 47,9\% dipengaruhi oleh variabel-variabel lain yang tidak diteliti dalam penelitian ini. 


\section{KESIMPULAN DAN SARAN \\ Kesimpulan}

1. Nilai t-hitung $<$ t-tabel $(-0,590<1,672)$ artinya H0 diterima ada pengaruh positif pendidikan kewirausahaan terhadap motivasi berwirausaha mahasiswa pendidikan ekonomi Universitas. Nilai t-hitung > t-tabel $(5,904>1,672)$ artinya H0 ditolak tidak ada pengaruh positif keterampilan berwirausaha terhadap motivasi berwirausaha mahasiswa pendidikan ekonomi Universitas Negeri Medan.

2. Nilai F-hitung > F-tabel $(31,020>3,159)$ artinya $\mathrm{H} 0$ ditolak tidak ada pengaruh positif pendidikan kewirausahaan dan keterampilan berwirausaha terhadap notivasi berwirausaha mahasiswa pendidikan ekonomi Universitas Negeri Medan.

3. Nilai R2 sebesar 0,521, berdasarkan nilai tersebut berarti $52,1 \%$ perubahan pada variabel motivasi berwirausaha (Y) dipengaruhi oleh variabel pendidikan kewirausahaan (X1) dan keterampilan berwirausaha (X2), sedangkan 47,9\% dipengaruhi oleh variabel-variabel lain yang tidak diteliti dalam penelitian ini.

\section{Saran}

Kecenderungan variabel pendidikan kewirausahaan masih dalam ketegori cukup sehingga perlu ditingkatkan melalui pengembangan model pendidikan kewirausahaan dengan materi pembelajaran dengan berbasis kewirausahaan, strategi metode pembelajaran yang variatif, inovatif dan menyenangkan. Variabel motivasi dan keterampilan berwirausaha sudah dalam kategori tinggi sehingga perlu dipertahankan.

\section{REFERENSI}

Agus Wibowo. (2011). Pendidikan Kewirausahaan (Konsep dan Strategi). Yogyakarta: PUSTAKA PELAJAR

Alma, Buchori. 2011. Kewirausahaan. Bandung: Alfabeta.

Anas Sudijono. (2009). Pengantar Evaluasi Pendidikan. Jakarta: Rajawali Pers

Arman Hakim Nasution dkk.(2007). Etrepreneurship Membangun Spirit Teknopreneurship. Yogyakarta: C.V ANDI OFFSET

Basrowi. (2011). Kewirausahaan untuk Perguruan Tinggi. Bogor: Ghalia Indonesia.
NIAGAWAN Vol 7 No 2 Juli 2018

D. Mason Robert dan A. Lind Dounglas. (1996). Teknik Statistika untuk Bisnis dan Ekonomi Jilid 1 dan 2. Jakarta: Erlangga

Daryanto. (2012). Pendidikan Kewirausahaan. Yogyakarta: Gava Media

Eko Putro Widoyoko. (2012). Teknik Penyusunan Instrumen Penelitian. Yogyakarta: PUSTAKA PELAJAR

Ghozali, Imam. 2016. Aplikasi

Analisis Multivariate dengan Program IBM SPSS 23.

Semarang: Badan Penerbit Universitas Diponegoro.

H.A.Rusdiana. (2014). Kewirausahaan Teori dan Praktik. Bandung: CV PUSTAKA SETIA

Riyanti, Benedicta Prihatin Dwi. 2003. Kewirausahaan dari Sudut Pandang Psikologi Kepribadian. Jakarta: Grasindo.

Sugiyono. (2012). Metode Penelitian Kuantitatif, Kualitatif, dan R\&D. Bandung: CV ALFABETA

Suharsimi Arikunto.(2010).Prosedur Penelitian Suatu Pendekatan Praktek. Jakarta:PT RINEKA CIPTA

Suharyadi, Nugroho. A., Purwanto., \& Maman. F. Kewirausahaan Membangun Usaha Sukses Sejak usia Muda. Jakarta: Salemba Empat.

Suryana. 2013. Kewirausahaan Pedoman Praktis: Kiat dan Proses Menuju Sukses. Jakarta: Salemba Empat.

Tatang S. (2012). Ilmu Pendidikan. Bandung: CV PUSTAKA SETIA

Wasty Soemanto.(1996).Pendidikan Wiraswasta.Jakarta:Sinar Grafika Offset.

Winarno. (2011). Pengembangan Sikap Entrepreneurship dan Intrapreneurship. Jakarta: PT INDEKS 